\title{
Juniper encroachment into aspen in the Northwest Great Basin
}

\author{
TRAVIS G. WALL, RICHARD F. MILLER, AND TONY J. SVEJCAR
}

Authors are research associate, professor of Rangeland Resources Oregon State University, and supervisory rangeland scientist, USDA-ARS. All are located at the Eastern Oregon Agricultural Research Center, 67826-A Hwy 205, Burns, Ore. Author is currently an instructor at BYU Idaho, Rexburg, ID

\begin{abstract}
In the northwest Great Basin, western juniper (Juniperus occidentalis subsp. occidentalis Hook.) is encroaching into aspen (Populus tremuloides Michx.) communities. There is a concern that aspen communities in this region are in a state of decline, but their status has not been documented. This study determined the timing, extent, and some of the effects of this expansion. Ninety-one aspen stands were sampled for density, canopy cover, age, stand structure, and recruitment of western juniper and aspen. Soils and tree litter beneath aspen and western juniper were collected to analyze the effects of western juniper on soils. Additionally, 2 large aspen complexes in southeast Oregon were intensively aged to determine disturbance (fire) frequencies. Western juniper encroachment peaked between 1900 and 1939 with $77 \%$ of all juniper trees sampled having been established during this period. Three-fourths of aspen stands sampled have established populations of western juniper. Twelve percent of aspen stands sampled were completely replaced by western juniper and another $23 \%$ dominated by western juniper. Average density of western juniper in aspen sites was 1,573 trees $\mathrm{ha}^{-1}$. Seventy percent of aspen stands sampled had zero recruitment of new aspen. Aspen stands averaged 98 years old. There was an inverse correlation between aspen canopy cover and western juniper canopy cover. Soils influenced by western juniper had a higher $\mathrm{C}: \mathrm{N}$ ratio, $\mathrm{pH}$, salts, lime, and sulfate, and lower amounts of magnesium, iron, copper, and manganese. Aspen litter had a lower $\mathrm{C}: \mathrm{N}$ ratio than western juniper litter. Two major aspen complexes sampled had even-age, 2-tiered even-age, and multiple-age aspen trees. The absence of presettlement juniper within all sampled aspen stands suggests fire was the primary stand-replacing disturbance in these northwest Great Basin aspen communities. The lack of fire coupled with aspen stand decadence and low recruitment levels will allow for the continued encroachment and replacement of aspen communities by western juniper in the northwest Great Basin.
\end{abstract}

Key Words: Juniperus occidentalis subsp. occidentalis, Populus tremuloides, succession, age structure, disturbance.

The Eastern Oregon Agricultural Research Center (EOARC), and Bureau of Land Management Districts Burns Ore, Lakeview Ore, and the Alturas Calif area office supported this research. The Oregon State University Agricultural Experiment Station and USDA Agricultural Research Service jointly operate EOARC. The authors wish to thank Dale Bartos, Lee Eddleman, Charles Kay, Bill Romme, and 2 anonymous reviewers for their constructive comments.

Oregon State Agricultural Experiment Station Technical Paper Number 11738.

Manuscript accepted 14 Jan. 01.

\section{Resumen}

En la Gran Cuenca del noroeste el "Western juniper" (Juniperus occidentalis subsp. occidentalis Hook.) esta invadiendo las comunidades de "Aspen" (Populus tremuloides Michx.). Existe una preocupación respecto a si las comunidades de "Aspen" de esta región están en un estado de deterioro, pero este punto no ha sido documentado. Este estudio determinó la época, cantidad y algunos efectos de esta expansión. Se muestrearon 91 poblaciones de "Aspen" en las cuales se midió la densidad, cobertura de la copa, edad, estructura de la población y establecimiento de "Western juniper" y "Aspen". Bajo los árboles de "Aspen" y "Western juniper" se colectó suelo y mantillo de árboles para analizar los efectos del "Western juniper" en los suelos. Adicionalmente 2 grandes complejos de "Aspen" situados en el sudeste de Oregon fueron intensivamente muestreados para conocer su edad y determinar las frecuencias de disturbio (fuego). La invasión de "Western juniper" alcanzó su pico entre 1900 y 1939, periodo en el cual se estableció el $77 \%$ de los árboles de "Juniper" muestreados. En el $\mathbf{7 5 \%}$ de las poblaciones de "Aspen" muestreadas se habían establecido poblaciones de "Western juniper". El $12 \%$ de estas poblaciones de "Aspen" fueron completamente remplazadas por "Western juniper" $y$ otro $23 \%$ fue dominado por "Western juniper". La densidad promedio de "Western juniper" en los sitos de "Aspen" fue de 1,573 árboles $\mathrm{ha}^{-1}$. El $70 \%$ de las poblaciones de "Aspen" muestreadas no presentaron establecimiento de nuevas plantas de esta especie. Las poblaciones de "Aspen" promediaron una edad de 98 años. Hubo una correlación inversa entre la cobertura de copa del "Aspen" y la cobertura de copa del "Western juniper". Los suelos influenciados por "Western juniper" tuvieron valores mas altos en la relación $\mathrm{C}: \mathrm{N}$, $\mathrm{pH}$, sales, cal y sulfato y por otra parte tuvieron menores cantidades de magnesio, fierro, cobre y manganeso. El mantillo de "Aspen" tuvo una menor relación C:N que el mantillo de "Western juniper". Los dos complejos principales de "Aspen" que se evaluaron tuvieron una edad uniforme, 2 estratos de edad uniforme y árboles de "Aspen" de edad múltiple. Todas las poblaciones de "Aspen" estudiadas presentaron ausencia de "Juniper" antes de la de colonización, lo que sugiere que el fuego fue el principal factor de remplazo de las poblaciones de especies en estas comunidades de "Aspen de la Gran Cuenca del noroeste. La falta de fuego acompañada de la decadencia de la población de "Aspen" y sus bajos niveles de establecimiento permitirán que en la Gran Cuenca del noreste ocurra una invasión continua y el remplazo de las comunidades de "Aspen" por comunidades de "Western juniper". 
Quaking aspen (Populus tremuloides Michx. $)^{1}$ communities are on the decline throughout the western United States (Bartos and Campbell 1998a, Miller and Rose 1995). Encroachment of conifers has contributed to a $60 \%$ decline in aspen dominated landscapes on national forests across Utah (Bartos and Campbell 1998a). Although a considerable amount of work has been conducted in the Rocky Mountain region, little has been done to evaluate the status of aspen in the northwest Great Basin (northwest Nevada, northeast California, and southeast Oregon). Miller and Rose (1995) reported that western juniper (Juniperus occidentalis var. occidentalis Hook.) was actively encroaching into aspen stands on Steens Mountain, Oregon, below $2120 \mathrm{~m}$. However, neither the status of stand structure and age of aspen communities are known for the northwest Great Basin nor the extent of juniper invasion into these stands.

Although aspen communities constitute a small portion of the semi-arid northwest Great Basin, they add diversity to landscapes that are predominately sagebrush (Artemisia sp.) and juniper. In southeastern Oregon, 84 wildlife species reproduce and 110 wildlife species forage within aspen/grass communities and 95 wildlife species reproduce and 117 wildlife species forage within aspen/mountain big sagebrush (Artemisia tridentata subsp. vaseyana Beetle, Rhodora $)^{1}$ communities (Maser et al. 1984). Aspen communities are also very productive in terms of herbaceous plant growth and species diversity. Aspen are generally recognized as having more lush undergrowth than neighboring coniferous forests (Mueggler 1985). The herbaceous vegetation occurs as a multilayered mixture of shrubs, forbs, and grasses and consists of a broad combination of over 300 species (Houston 1954). Bartos and Campbell (1998b), state that when conifers overtake aspen communities, less water is available to the watershed, biomass of understory vegetation is significantly reduced, and the diversity of wildlife and plant species declines. The greatest concern is the loss of aspen once a conifer community becomes established because aspen does not readily establish from seed (McDonough 1985, Mitton and Grant 1996).

The goals of this study were to: (1) assess the extent and timing of western juniper encroachment into aspen communities; (2) evaluate aspen stand structure, age structure, and determine pre- and post-

${ }^{1}$ Nomenclature is from Cronquist et al. (1972) settlement disturbance intervals; and (3) determine if western juniper alters soils previously occupied by aspen in the northwest Great Basin.

\section{Methods}

\section{Site Description}

The study was located in the High Desert and Klamath Ecological Provinces (Cronquist et al. 1972, Bailey 1994, Anderson et al. 1998) in southeast Oregon, northeast California, and northwest Nevada (latitudes $40^{\circ} 55^{\prime}$ to $43^{\circ} 00^{\prime}$ and longitudes $118^{\circ} 30^{\prime}$ to $120^{\circ} 45^{\prime}$ ) (Fig.1). Desert basins, uplands, canyons, and fault block mountains typify the geography of these 2 provinces. Shrub-grass communities associated with aspen are predominantly mountain big sagebrush with various degrees of low sagebrush (Artemisia arbuscula Nutt.), rabbitbrush (Chrysothamnus sp. Nutt.), bitterbrush (Purshia tridentata (Pursh) DC.) and snowberry (Symphoricarpos oreophilus A. Gray) with fescues (Festuca sp. L.), wheatgrasses (Agropyron sp. Gaertn.), and needlegrasses (Stipa sp. L.). Tree communities include western juniper, mountain mahogany (Cercocarpus ledifolius Nutt.), and aspen. Climate is cool and semi-arid characterized by cold wet winters and hot dry summers. Precipitation falls primarily as snow in November, December, and January and as rain in March through June.

Aspen stands in the shrub steppe frequently occupy sites along the north and northeast base of ridges where snow drifting increases available moisture enabling these areas to sustain aspen in an otherwise semi-arid environment. Aspen stands studied varied in elevation from a high of $2,120 \mathrm{~m}$ to a low of $1,494 \mathrm{~m}$. Within this elevation, yearly precipitation varies from 30 to $40 \mathrm{~cm}$.

Aspen stands can be complex with several layers of shrubs, tall forbs, low forbs, grasses, and annuals. In contrast, stands can also be very simple with even-aged aspen and a general assembly of grasses. Shrub genera typically found within aspen stands include: Symphoricarpos Duhamel., Rosa L., Amelanchier Medik., Prunus L., and Berberis L. Forb genera include: Thalictrum L., Osmorhiza Raf., Geranium L., Aster L., Lathyrus L., Achillea L., Galium L., and Senecio L. Graminoid genera include: Agropyron Gaertn., Bromus L., Elymus L., Poa L., and Carex L. Soils that characterize these semi-arid aspen stands were formed from igneous rock (basalt) and are typically loamy to sandy loam mixed frigid Pachic Haploxerolls, > $1 \mathrm{~m}$ in depth.

\section{Stand Selection and Plot Layout}

We made a general search for aspen stands $>0.5$ ha in the High Desert and Klamath Ecological Provinces. We also contacted the local federal land management agencies for known locations of aspen stands. We sampled all upland stands within the western juniper belt, $<2,120 \mathrm{~m}$ in elevation that could be found. In each stand

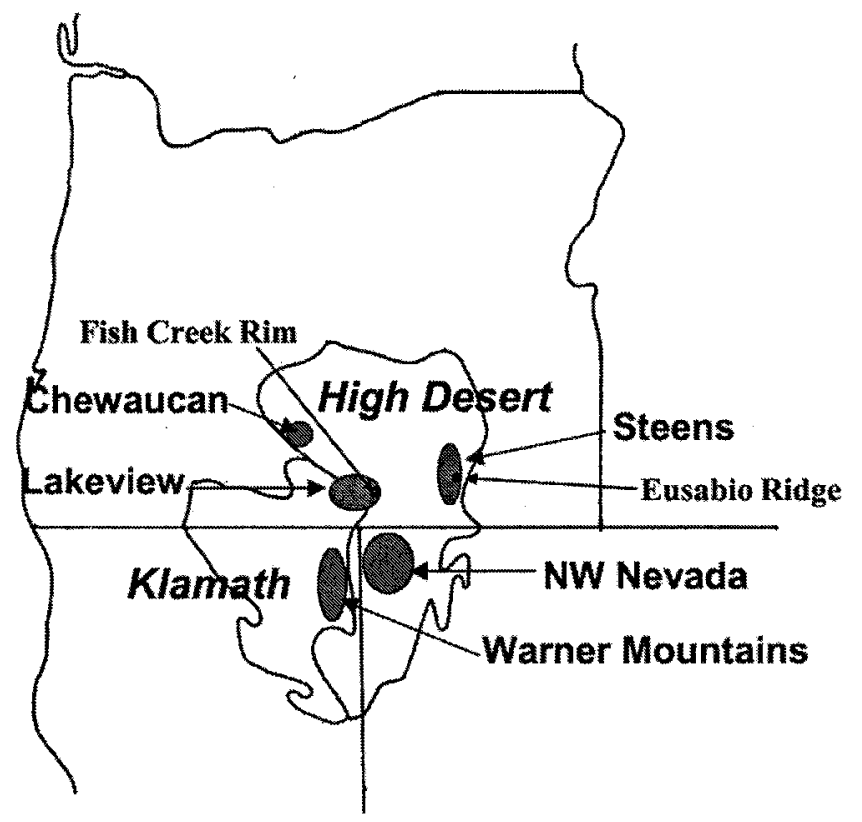

Fig. 1. General locations of aspen stands sampled across the High Desert and Klamath Ecological Provinces. 
sampled, a circular plot $15 \mathrm{~m}$ in diameter was positioned entirely within the aspen community. In stands greater than 1 ha, several circular plots were randomly placed to characterize the community. A total of 91 aspen stands were sampled.

\section{Stand Data Collection}

Within each $15 \mathrm{~m}$ circular plot all live and dead stems of juniper and aspen were counted and assigned to a height class. Adult aspen were defined as trees equal to or greater than $75 \%$ of stand height. Aspen trees considered to have potential for recruitment were equal to or greater than 2 $\mathrm{m}$ tall up to $75 \%$ of stand height. Trees less than $2 \mathrm{~m}$ in height were typically browsed, so recruitment potential for this height class was assumed to be very limited.

In every stand sampled, 5 of the largest aspen and 5 of the largest western juniper based on height and stem diameter (assumed to potentially be the oldest) were measured for height, diameter, and sampled with an increment corer. This was to establish the age of the dominant aspen trees and approximate time of initial juniper encroachment. Trees that were too small to core were cut at ground level to obtain a cross-section slab. Aspen cores and slabs were stained with phloroglucinol, sanded, and then aged by counting growth rings under a dissecting microscope. Phloroglucinol helped distinguish the very faint annual rings in the sapwood.

To determine if aspen community characteristics influence juniper encroachment, aspen and juniper canopy cover, canopy height, stand age, aspect, slope, and elevation data were collected. A spherical densiometer was used to measure overstory canopy cover for aspen and western juniper within the $15 \mathrm{~m}$ circular plot. Tree height was determined by measuring length of dead fallen trees in combination with visual estimates of live trees. Aspect, slope, elevation, estimated percent herbaceous cover, and estimated percent bare ground were recorded for each site sampled. With this information, statistical correlations were computed between juniper canopy cover and density versus aspen overstory canopy cover, canopy cover height, stand age, aspect, slope, elevation, percent herbaceous cover, and percent bare ground.

\section{Disturbance Interval}

To determine disturbance intervals in aspen within the northwest Great Basin, 2 sites with the largest stands were sampled. The first, a continuous 71 ha stand, is located along Eusabio Ridge and Ankle
Creek on the southern end of Steens Mountain southwest of Burns, Ore. The second, a series of adjacent stands totaling approximately 35 ha was located on Fish Creek Rim north of Adel, Ore.

The Eusabio stand was systematically sampled by walking several transects from toe-slope to the ridge crest. Transects were placed every 80 to 100 meters across the length of the $3 \mathrm{~km}$ long stand. Along these transects, plots were established every 25 to $50 \mathrm{~m}$. The variation in distance between plots was determined by stand structure; i.e., plots were centered in sites with similar tree density and tree size and not placed to overlap areas of varying stand structure. The broad distribution of plot locations captured the variability of aspect, elevation, and slope within the stand. Within each plot, increment cores were collected from the 10 largest aspen trees to determine age distributions within the stand. Within the 71 ha stand on Eusabio Ridge, a total of 100 plots and 1,000 aspen were sampled.

The series of stands located on Fish Creek Rim were situated along a northwest to southeast set of ridges approximately 11 kilometers long. Starting at the northwest end and working southeast, each individual aspen stand was sampled. Similarly, the 10 largest aspen trees cored to determine age within each plot. A total of 28 plots with 280 aspen were sampled over approximately 35 ha.

All 1,280 aspen cores were stained (with phloroglucinol), sanded, and aged by ring counts. Because aspen sprouts after disturbance, the oldest trees in each of the 128 plots revealed the approximate timing of the last major disturbance within each of the plots. The large number of plots allowed us to construct a stand disturbance history for the 2 stands. A pre-Euro American settlement (pre-1870) mean and range of years between disturbances were calculated for each aspen complex sampled.

\section{Soil}

Soils were sampled using a randomized block design with 5 blocks. These 5 blocks were placed in aspen stands greater than 1.5 ha growing on Steens Mountain. Block size depended on aspen stand characteristics, such as distance between treatments and shape of aspen stands. Each block had the following 2 treatments:

1. Soils influenced by aspen.

2. Soils once influenced by aspen but now dominated and influenced by western juniper.

Five sub-samples were collected 2 thirds inward from the drip line of the present dominant canopy in each treatment. The top $10 \mathrm{~cm}$ of soil was sampled with a hand shovel, collecting approximately 500 g per sample. A total of 10 soil sub-samples were collected in each block with 50 total sub-samples for the 5 blocks $(n=25$ for each treatment). The soil sub-samples were sent to a soils lab where standard techniques were used to analyze for $\mathrm{C}: \mathrm{N}$ ratio, $\mathrm{pH}, \mathrm{CEC}, \%$ lime, \%OM, and plant available $\mathrm{C}, \mathrm{N}, \mathrm{P}, \mathrm{K}, \mathrm{Ca}, \mathrm{Mg}, \mathrm{Na}, \mathrm{Zn}, \mathrm{Fe}$, $\mathrm{Mn}, \mathrm{Cu}, \mathrm{B}$, and sulfate. Additionally, at each soil sub-sample collection site for juniper-dominated treatments, juniper were cored and aged to determine duration of their influence over the site sampled.

At each sub-sample collection site, resident litter depth was measured $(n=50$ across the 5 blocks). A litter trap approximately $40 \times 90 \mathrm{~cm}$ was placed under each treatment in all 5 blocks. These traps captured current litter fall from 1 August to 1 November 1998. The 2 litter types (aspen and western juniper) were analyzed with a CHN analyzer (Perkin Elmer 2400 Series II, Norwalk, CT $)^{2}$ to determine differences in carbon and nitrogen content and $\mathrm{C}: \mathrm{N}$ ratios.

\section{Data Analysis}

The statistical package SAS was used for all data analysis (SAS Institute 1990). Stepwise multiple regression was used to determine if aspen overstory canopy cover, canopy cover height, stand age, aspect, slope, and elevation affected western juniper canopy cover and density. Soil data were analyzed as a randomized block with 2 treatments. ANOVA's were calculated to determine if soil and litter variables differed between the 2 treatments.

\section{Results}

\section{Western juniper encroachment.}

Western juniper encroachment into aspen stands has occurred throughout the shrub steppe region in southeast Oregon, northwest California and northwest Nevada. Of the 91 aspen stands sampled, $86(95 \%)$ contained western juniper. Twelve percent of the stands sampled were completely replaced by western juniper. In another $23 \%$ of stands, western juniper was the dominant tree canopy. Western juniper was common but not yet dominant in $42 \%$, present but not common in $18 \%$, and absent in $5 \%$ of the aspen stands sampled. The average density of

${ }^{2}$ Mention of a trade name does not indicate endorsement by USDA or Oregon State University. 


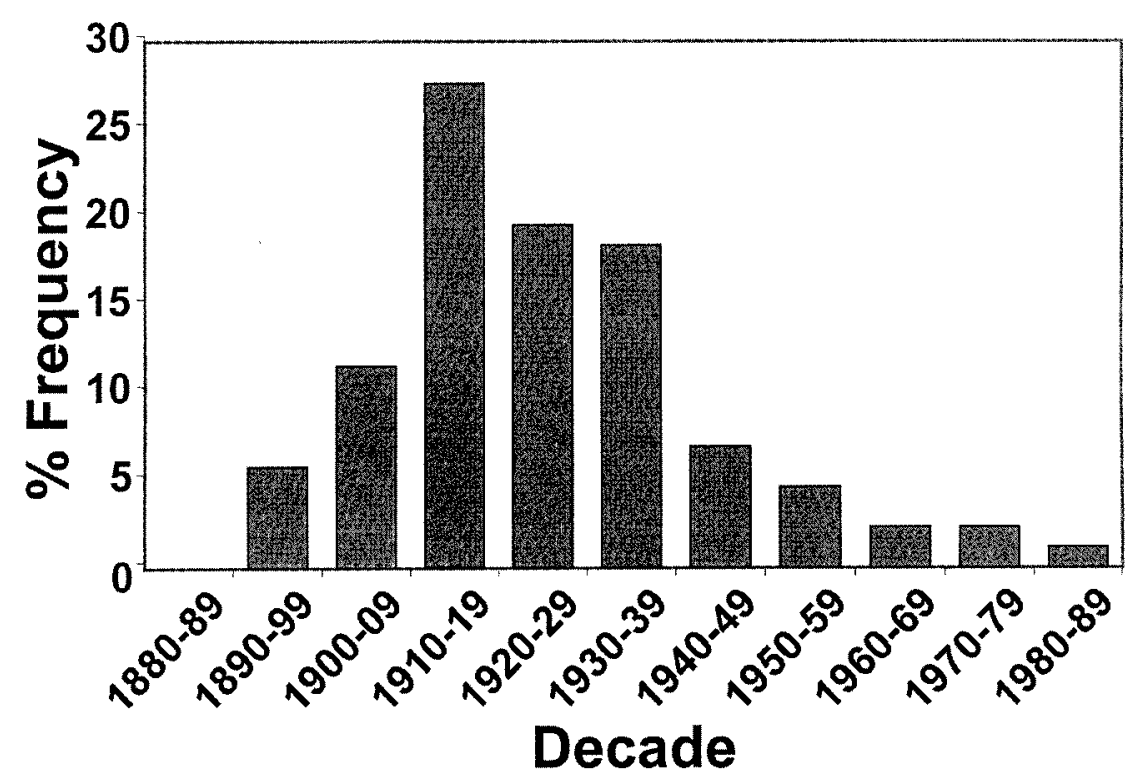

Fig. 2. Decade when juniper initially became established into aspen communities across the northwestern Great Basin.

western juniper was 1,573 trees $\mathrm{ha}^{-1}$ of aspen sampled ( $\mathrm{SE}=133.7)$.

Western juniper canopy cover averaged $21 \%(\mathrm{SE}=2.5)$ across the 86 aspen communities containing juniper. Based on percent composition between western juniper cover and aspen cover, western juniper constitutes $27 \%$ of the total overstory canopy cover in aspen stands across the study area.

Western juniper encroachment into aspen peaked between 1900 and 1939 with $77 \%$ of all trees sampled establishing during this 39-year period (Fig. 2). The average age of western juniper was 72 years old (standard error $=2.0$ ). Only $5 \%$ were greater than 100 years old and none exceeded 107 years.

\section{Aspen stand structure.}

Aspen stands averaged 98 years old ( standard error $=3.2$ ) with $85 \%$ of the stands falling between 70 and 130 years old. Forty-eight percent of the aspen stands were greater than 100 years old.

Mean density of mature live aspen trees in stands sampled was 953 trees ha-1 $(\mathrm{SE}=$ 88.1). Aspen stand density of adult dead trees averaged 123 trees $^{-1} \mathrm{~h}^{-1}$ (standard error $=18.9$ ). Where recruitment trees occurred, they averaged 143 trees $\mathrm{ha}^{-1}(\mathrm{SE}=50.1)$. However, $70 \%$ of aspen stands sampled had 0 recruitment. Aspen canopy cover averaged $59 \%$ and total tree cover, aspen and juniper, averaged $73 \%(\mathrm{SE}=3.0)$.

\section{Variables affecting western juniper encroachment.}

Several variables were significantly $(\mathrm{p}<$ .05 ) related to western juniper encroachment (Table 1). Western juniper and aspen cover expressed the strongest relationship. As aspen cover decreased western juniper cover increased. Other parameters reportindicated they explained only a small degree of the variability. Elevation and aspect are the 2 site variables that were significantly correlated to western juniper cover. As elevation increased western juniper cover decreased. East and southeast facing aspen stands contained higher densities of juniper than north and northeast facing stands.

Simple regression revealed that as juniper cover increased in aspen stands, herbaceous plant cover decreased and bare ground increased. ed were significant but their $\mathrm{R}^{2}$ values

\section{Disturbance}

Mean ages of dominant aspen canopy trees tended to cluster around several establishment periods across the 2 large aspen stands suggesting portions of these stands had been disturbed at different time periods. Within the 71 ha Eusabio/Ankle Creek aspen complex, 52 out of 100 (52\%) plots were $73-80$ years old (Fig. 3) each with an age spread of less than 10 years. Another 17 plots were even-aged ranging from 119-132 years. The remaining 31 plots had a spread of ages greater than 10 years. However, these 31 plots did have even-aged components. For example, a plot could have had 8 trees 128 years old and 2 trees 112 years old. Another plot may have had 3 trees 160 years old and 7 trees 100 years old. In none of the plots did the 10 largest trees represent more than 2 age classes.

Within the Fish Creek/Cox Springs aspen complex 2, of 28 plots were 62-64 years old, 3 plots were 95-96 years old, 3 plots were 117-119 years old, and 3 plots were 124-128 years old (Fig. 4). On 9 plots, a 2-tiered even-aged class occurred. The remaining 8 plots had no pattern at all and consisted of several ages.

$\begin{aligned} & \text { Table 1. Multiple Regression relationships between aspen, western juniper, and geography vari- } \\
& \text { ables. }\end{aligned}$
\begin{tabular}{lcc} 
& $\mathrm{R}^{2}$ & p-value \\
\hline \hline Variables & .80 & .0001 \\
Juniper cover vs. aspen cover & .19 & .0001 \\
Juniper cover vs. aspen density & .13 & .0004 \\
Juniper cover vs. elevation & .10 & .0018 \\
Juniper cover vs. bare ground & .18 & .0001 \\
Juniper cover vs. herbaceous cover & .04 & .0365 \\
Juniper density vs. aspect & .04 & .0313 \\
Juniper density vs. aspen cover & .06 & .0187 \\
Juniper density vs. aspen density & .32 & .0001 \\
Aspen age vs. aspen cover &
\end{tabular}

\section{Effects of western juniper on soil.}

Western juniper varied from 75 to 85 years old across the soil plots located on Steens Mountain. Average juniper litter depth across the juniper influenced plots was $10 \mathrm{~cm}( \pm 2 \mathrm{~cm})$. The average litter depth for aspen influenced soils was $3 \mathrm{~cm}$ $( \pm 1 \mathrm{~cm})$.

There was no significant difference in soil carbon and nitrogen content between the 2 treatments. However, the $\mathrm{C}: \mathrm{N}$ ratio and $\mathrm{pH}$ proved to be significantly greater in the juniper than in aspen plots (Table 2). Soils influenced by western juniper also contained greater amounts of salts, lime, and sulfate, and lower amounts of magnesium, iron, manganese, and copper. The increase in $\mathrm{pH}$ beneath juniper may be 
Table 2. Mean, standard error, and p-value for different soil variables beneath the canopies of aspen and western juniper soil treatments.

\begin{tabular}{|c|c|c|c|c|c|}
\hline Variable & $\underset{\bar{X}}{\text { Aspen }}$ & SE & $\begin{array}{c}\text { Juniper } \\
\overline{\mathrm{X}}\end{array}$ & SE & p-value \\
\hline$\overline{\mathrm{C}: \mathrm{N} \text { ratio }}$ & 12.360 & 0.254 & 13.284 & 0.204 & 0.0102 \\
\hline $\mathrm{p}^{\mathrm{H}}$ & 6.800 & 0.042 & 7.380 & 0.043 & 0.001 \\
\hline Salts & 0.352 & 0.026 & 0.432 & 0.020 & 0.0190 \\
\hline CEC & 17.690 & 0.394 & 16.720 & 0.248 & 0.0036 \\
\hline$\%$ Lime & 0.620 & 0.044 & 0.820 & 0.049 & 0.0016 \\
\hline$\% \mathrm{OM}$ & 5.256 & 0.122 & 5.088 & 0.098 & 0.1918 \\
\hline $\mathrm{C} \mathrm{mg} \mathrm{kg}$ & 7.040 & 0.320 & 7.255 & 0.366 & 0.6500 \\
\hline $\mathrm{N} \mathrm{mg} \mathrm{kg}^{-1}$ & 0.568 & 0.022 & 0.542 & 0.022 & 0.3444 \\
\hline $\mathrm{P} \mathrm{mg} \mathrm{kg}^{-1}$ & 56.800 & 4.926 & 47.960 & 2.602 & 0.1168 \\
\hline $\mathrm{K} \mathrm{mg} \mathrm{kg}^{-1}$ & 549.560 & 25.373 & 536.880 & 38.254 & 0.6445 \\
\hline Ca mg kg & 2786.400 & 110.027 & 2560.800 & 140.207 & 0.1032 \\
\hline $\mathrm{Mg} \mathrm{mg} \mathrm{kg}^{-1}$ & 245.080 & 2.064 & 228.040 & 6.592 & 0.0074 \\
\hline $\mathrm{Na} m g \mathrm{~kg}^{-1}$ & 86.080 & 5.660 & 79.160 & 5.429 & 0.2858 \\
\hline $\mathrm{Zn} \mathrm{mg} \mathrm{kg}^{-1}$ & 3.448 & 0.386 & 3.712 & 0.624 & 0.6396 \\
\hline $\mathrm{Fe} \mathrm{mg} \mathrm{kg}{ }^{-1}$ & 29.016 & 3.060 & 13.936 & 0.539 & 0.0001 \\
\hline Mn mg kg ${ }^{-1}$ & 5.920 & 0.622 & 2.980 & 0.221 & 0.0001 \\
\hline $\mathrm{Cu} \mathrm{mg} \mathrm{kg}{ }^{-1}$ & 0.524 & 0.040 & 0.408 & 0.030 & 0.0071 \\
\hline $\mathrm{B} \mathrm{mg} \mathrm{kg}{ }^{-1}$ & 0.364 & 0.015 & 0.344 & 0.015 & 0.2261 \\
\hline Sulfate $\mathrm{mg} \mathrm{kg}^{-1}$ & 5.280 & 0.212 & 6.720 & 0.464 & 0.0029 \\
\hline
\end{tabular}

partially attributed to the increase in lime. Bates et al. (2002) also reported increases in soil $\mathrm{pH}$ beneath western juniper canopies compared to tree interspaces. Nutrient composition for aspen and juniper litter was also significantly different (Table 3). Carbon and nitrogen content were greater and $\mathrm{C}: \mathrm{N}$ lower in aspen litter than in juniper litter.

\section{Discussion}

\section{Juniper Expansion}

Since the 1890 s, western juniper has been actively invading over $90 \%$ of aspen stands below 2,120 $\mathrm{m}$ in the northwest Great Basin. Across this geographic region, western juniper density in aspen sites typically exceeded 500 trees ha ${ }^{-1}$, with approximately one third of aspen stands sampled being replaced or dominated by western juniper.

Conifer expansion into aspen is widespread across the Western United States. In most instances, aspen is considered a seral species replaced by more shade tolerant conifers such as Douglas fir (Pseudotsuga menziesii Mirbel), Engelman spruce (Picea engelmanii Parry), and sub-alpine fir (Abies lasiocarpa Hook.) in the absence of disturbance (Mueggler 1985). Encroachment of these conifers has contributed to a $60 \%$ decline in aspen dominated landscapes on national forests across Utah (Bartos and Campbell 1998a). Although western juniper is a drought-adapted conifer, its with changes in fire return intervals, optimal climatic conditions for juniper seed production and establishment, and introduction of livestock (Miller and Wigand 1994, Miller and Rose 1995, 1999).

\section{Disturbance}

Fire has been reported to be an important factor in facilitating the long-term presence and health of aspen across the landscape (Baker 1925, Bartos and Mueggler 1981, Jones and DeByle 1985, Brown and DeByle 1987, DeByle et al. 1989). European settlement has altered fire regimes through elimination of aboriginal burning, fire suppression, livestock grazing, introduction of exotic plant species, and urbanization of the West (Kay 1997, Miller et al. 1994, Miller and Rose 1999). Herbivory and lack of fire are likely key factors in the recent expansion of western juniper and lack of aspen recruitment in communities throughout the northwest Great Basin.

Age structure data from the Eusabio Ridge and Fish Creek Rim aspen complexes revealed 3 age structures: evenaged, 2-tiered even-aged, and multipleaged sites. Kay and Bartos (2000) concluded that excessive herbivory on aspen creates even-aged stands and aspen protected from herbivory become multipleaged stands. On the other hand, Jones and DeByle (1985) state that even-aged aspen stands result from a sprouting response after a fire and that multiple-aged stands result from a slow die-off of over-mature trees and the subsequent prolonged regeneration period.

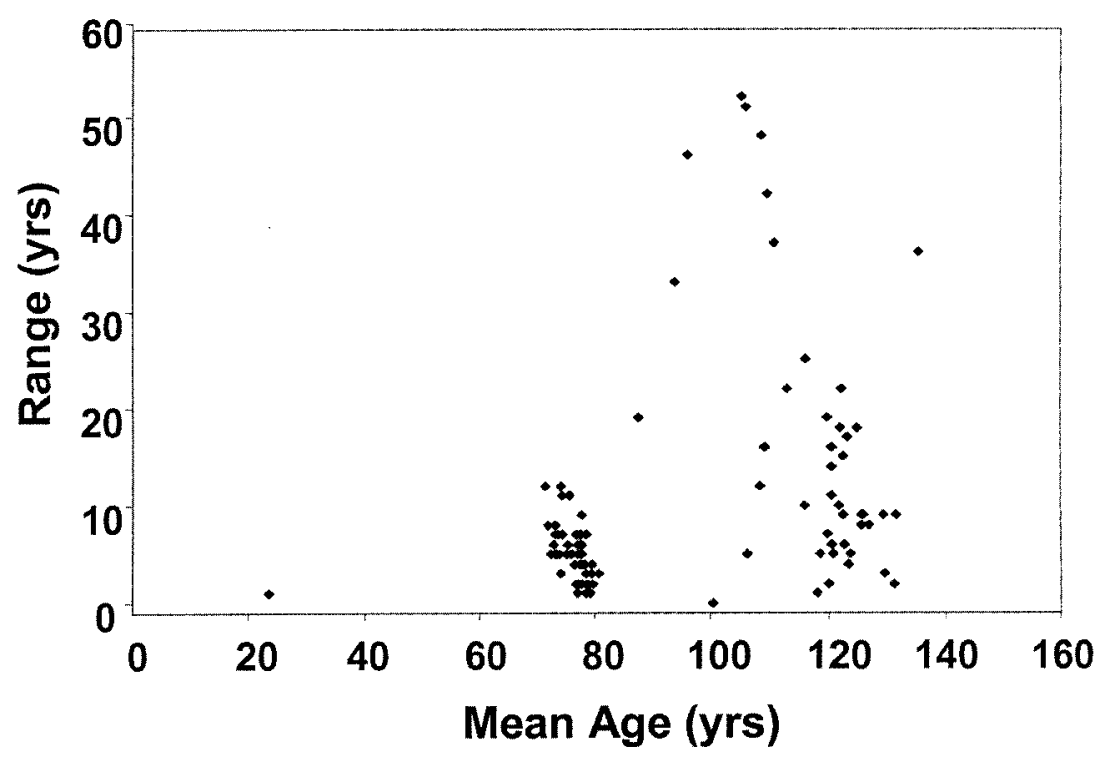

Fig. 3. Mean age and range of the10 largest overstory aspen trees in each plot in the Eusabio Ridge aspen complex. 
On Eusabio Ridge, $52 \%$ of the evenaged sites were about 80 years old, and $17 \%$ were about 125 years old (Fig. 4). Did fire or excessive herbivory or both create these even-aged sites? For the 2tiered, even-aged sites the age structure could have resulted from: 1) fire with some older surviving trees and a flush of regeneration, 2) fire with initial regeneration and then a secondary lag response of regeneration, or 3) brief lulls in herbivory pressure allowing new trees to establish. However, multiple-aged stands were lacking on Eusabio Ridge suggesting stand replacement disturbance events.

In the Fish Creek Rim aspen complex, even-aged sites of $60,95,118$, and 126 years old were found (Fig. 4). This suggests stand replacement disturbance occurring somewhere within the stand with a mean return interval of 16.5 years. In southern Colorado, fire had burned within a $77 \mathrm{~km}^{2}$ aspen stand nearly every decade between 1760 and 1870 (unpublished data, Romme et al.). Total stand replacement occurred about every 100 years. Fish Creek Rim may have experienced similar fire events. If aspen stand age structure on Fish Creek Rim had resulted from excessive herbivory, we would expect multiple aged tiers to be even aged across the stand. The data creates questions while the literature poses several potential interpretations.

Fire, disease, insects, herbivory, and natural mortality influence the age structure of aspen. Fire was a frequent disturbance process in adjacent mountain big sagebrush communities. Fire return intervals in the mountain big sagebrush alliance are typically 12 to 22 years, which limited western juniper encroachment (Miller and Rose 1999). In addition, the absence of presettlement juniper within all 91 aspen stands suggests fire was the primary stand-replacing disturbance in these northwest Great Basin aspen communities.

In the Chewaucan region of south-central Oregon, fire-scar data revealed fire return intervals ranged from 12 to 22 years prior to 1897 with the last major fire occurring in 1870 (Miller and Rose 1999). Hence, no recorded fire occurred in this area for a century. All aspen stands sampled in the Chewaucan region dated to the approximate time of the last largest fire in 1870. Although western juniper began establishing in the 1870 s in adjacent mountain sagebrush communities, encroacment into aspen did not occur until the mid 1890s. With the lack of fire for the past century, Chewaucan aspen stands linger in a state of decline. Established western juniper are on the brink of completely replacing these stands.

Long-term browsing of aspen regeneration by wild and domestic ungulates may limit aspen recruitment. Continuous or heavy grazing of aspen suckers jeopardizes the health, recruitment, and longevity of the stand (Bartos and Mueggler 1981, Bartos et al., 1991, DeByle 1985, Romme et al. 1995). If regenerating suckers are unable to overcome browsing pressure, then aspen stands cannot sustain

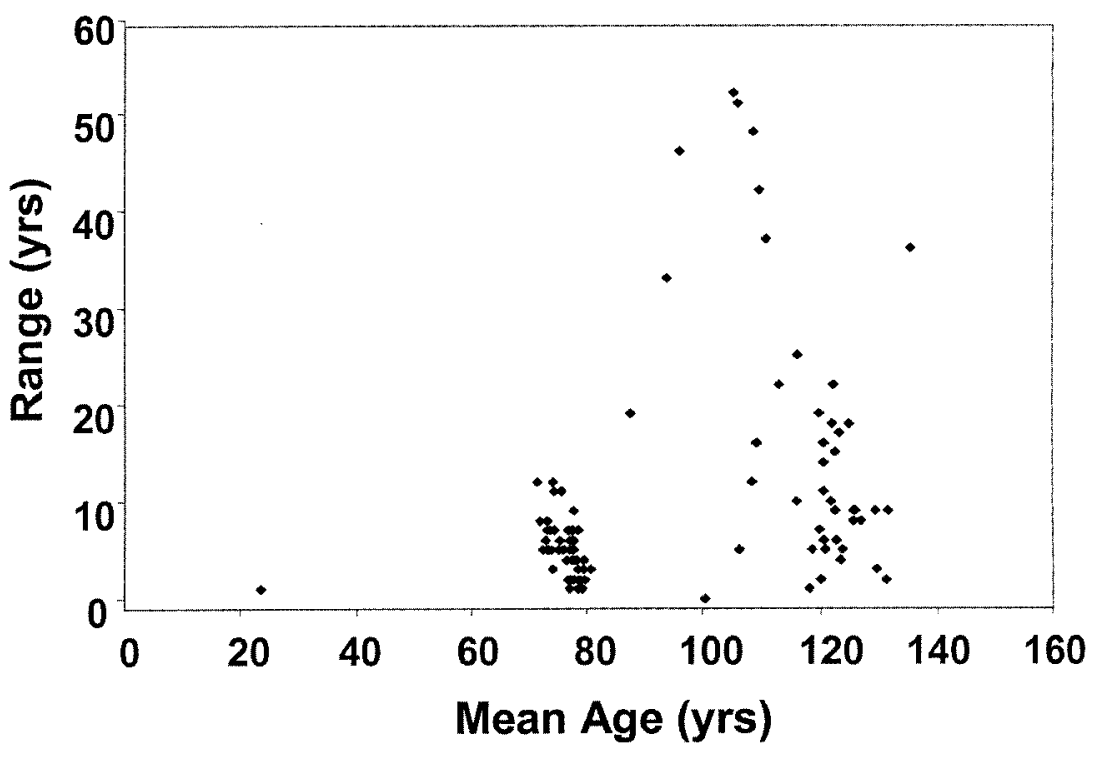

Fig. 4. Mean age and range of the10 largest overstory aspen trees in each plot in the Fish Creek Rim aspen complex. viable populations and persist amid the compounding effects of western juniper invasion and replacement. In our study, $70 \%$ of all aspen stands sampled had no active recruitment. The remaining $30 \%$ of aspen stands had active recruitment, but averaged only 143 juvenile trees ha ${ }^{-1}$. Mature or over-mature aspen stands with less than 1,235 suckers ha ${ }^{-1}$ may have regeneration problems and are at risk of being lost (Mueggler 1989, Bartos and Campbell 1998a). In essence, as adult aspen grow decadent and die in the northwest Great Basin, densities of juvenile aspen escaping from large ungulate use are not adequate to maintain the stand. We observed that terminal leader growth on most of the aspen suckers was absent due to browsing. Lack of regeneration due to excessive ungulate browsing of aspen suckers may allow western juniper to establish and accelerate succession to juniper woodlands. Reestablishment of aspen stands that are burned and subsequently sprout high densities of suckers may also be limited under heavy browsing pressure regardless of conifer encroachment (Bartos et al. 1994).

\section{Pattern of western juniper encroachment.}

The direct correlation between juniper and aspen canopy cover suggests strong interspecific competition between the 2 species. As aspen canopy cover decreased, juniper canopy cover increased ( $\mathrm{p}=$ .0001). Others have reported a significant negative correlation between juniper canopy cover with aspen canopy cover and density (Miller et al. 2000). Direct observation of juniper growth rings supports this competitive relationship. Beneath intact aspen canopies juniper growth rings were very tight, often with 30 to 40 rings $\mathrm{cm}^{-1}$. Within the same aspen stand individual juniper ring growth increased as much as $1 \mathrm{~cm} \mathrm{yr}^{-1}$ where mortality of aspen around the tree had opened the overhead canopy. Thus, aspen decadence may indirectly facilitate an increase in juniper growth. As aspen stands increase in age beyond 90 years, canopy cover declines $(\mathrm{p}=.0001)$. The fact that $75 \%$ of aspen stands sampled are greater than 90 years old suggests a decline in aspen canopy cover across the northwest Great Basin is likely occurring.

Several environmental factors also appear to influence the degree of juniper encroachment. Elevation had some effect on juniper canopy cover. As elevation increased, juniper canopy cover decreased. Since juniper are limited at upper eleva- 
Table 3. Mean, standard error, and p-value for carbon and nitrogen in litter collected beneath the canopies of aspen and western juniper.

\begin{tabular}{lccccc}
\hline \hline Variable & Aspen litter & SE & Juniper litter & SE & p-value \\
\hline C:N ratio & 45.310 & 7.191 & 76.637 & 4.458 & 0.0036 \\
$\%$ C & 51.036 & 0.81 & 48.802 & 0.503 & 0.0337 \\
$\% \mathrm{~N}$ & 1.228 & 0.163 & 0.646 & 0.040 & 0.0179 \\
\hline
\end{tabular}

tions by severe winter weather conditions and are not typically found above $2,120 \mathrm{~m}$, this correlation was expected (Miller et al. file data). Additionally, aspen stands that faced east or south-east had slightly higher densities of juniper than aspen stands that faced north or northeast. Slope and aspen height did not have any significant effects on western juniper densities or canopy cover. The relationship with elevation and aspect suggest juniper encroachment is more aggressive on the warmer sites. We would expect these sites to be more prone to fire. These correlations set forth geomorphic and biologic conditions that predispose a stand to juniper encroachment. These conditions are: 1) open aspen canopy cover $(<70 \%), 2)$ mature to overmature stands ( $>90$ years), 3) elevational location below $2,120 \mathrm{~m}, 4$ ) east or southeast facing stands.

Aspen stands with minimal juniper encroachment typically had over 3,000 aspen trees per ha and $>70 \%$ aspen canopy cover. Typically, herbaceous plant cover was $21 \%$. However, in stands where juniper was co-dominant to dominant in the overstory, aspen density was typically less than 1,425 tree/ha with a $20 \%$ aspen canopy cover and $11 \%$ herbaceous plant cover. Thus, understory vegetation in stands encroached upon by western juniper contrasted sharply with the lush, green understory in aspen dominated stands. Juniper encroached stands had higher amounts of bare ground and less herbaceous cover than non-invaded aspen.

\section{Effects on Soils}

Soils influenced by western juniper had a higher $\mathrm{C} / \mathrm{N}$ ratio and a higher $\mathrm{pH}$ than strictly aspen influenced soils (Table 2). This higher $\mathrm{C} / \mathrm{N}$ ratio can be attributed to the effect of western juniper litter on soils; juniper litter also has a higher $\mathrm{C} / \mathrm{N}$ ratio than aspen litter (Table 3).

Western juniper probably sequesters nutrients within the tree, not recycling them back into the soil as quickly as aspen. This difference is a result of the deciduous nature of aspen and the coniferous growth form of juniper. Other studies found that aspen leaf litter lost $42 \%$ of its weight during the first winter after leaf fall (Bartos and DeByle 1981). In comparison, western juniper needle litter on Steens Mountain lost only $17 \%$ of its mass over 2 years (Bates 1996). Aspen also shed approximately 1.4 times more leaf biomass annually than western juniper (Bartos and Debyle 1981, Bates 1996). Thus, aspen produces more litter, which decomposes faster than western juniper, resulting in a higher rate of nutrient cycling.

In addition to influencing soils, juniper encroachment may impact hydrologic cycles. Western juniper effectively intercepts rain and snow (Young and Evans 1984, Larsen 1993). As conifer canopy increases in an aspen community, it intercepts snow subjecting it to sublimation. This results in less water in the snowpack under the mixed aspen-conifer stand than under pure aspen (Johnston 1971). Conifers also use more water per year than aspen (Gifford et al. 1983, 1984, Jaynes 1978). Further study is required to determine the effects and changes in hydrologic cycles in aspen sites overtaken by western juniper.

\section{Management Implications}

Aspen stands in the northwest Great Basin are in a state of decline. Threefourths of the aspen communities below 2,133 m elevation have either been replaced, are being replaced, or have establishing populations of western juniper. The magnitude of western juniper encroachment demands immediate action. Without active management, stands of aspen in this region will continue to decline and may be permanently lost. The loss of aspen communities would decrease landscape diversity and remove a community type that is important to many wildlife species. Since establishment of aspen from seed is rare under current climatic conditions in the Intermountain Region (McDonough 1985), stands that are totally replaced by western juniper have likely passed a threshold from immediate planning and proactive management will allow for the restoration and maintenance of this resource.

The reintroduction of fire and the decrease of herbivore pressure are key factors in the restoration of aspen. To sustain or restore aspen, prescribed fire or allowed a deciduous to conifer woodland. Only natural fire are the best tools for eliminating young juniper and inducing aspen regeneration. In advanced cases, fine fuel levels may be too low to carry adequate fires. In addition, high fuel moisture in aspen communities commonly limits fire. These circumstances necessitate cutting western juniper within the stand one year prior to burning in order to use their dried foliage to carry a fire. Precautions should also be taken to protect young aspen suckers from excessive herbivory. The continued growth in elk populations in the northwest Great Basin will likely increase the browsing pressure on young aspen trees. Further studies on the degree and extent of herbivory in aspen stands as well as on effective means of control would help direct management in efforts to maintain aspen communities in the desert landscape. Key questions that need further study for stands being replaced by western juniper are: 1) at what point is an aspen stand beyond the threshold of restoration, and 2) how long will the parent root system stay intact and viable once no aspen trees are present?

\section{Literature Cited}

Anderson E.W., M.M. Borman, and W.C. Krueger. 1998. The Ecological Provinces of Oregon - a treatise on the basic ecological geography of the state. Oregon Agr. Exp. Sta., Corvallis, Ore.

Bailey, R.B. 1994. Description of the Ecoregions of the United States. USDA-FS Misc.Pub. 1391.

Baker, F.S. 1925. Aspen in the central Rocky Mountain region. USDA Bull. 1291.

Bartos, D.L. and R.B. Campbell. 1998a. Decline of quaking aspen in the Interior West -examples from Utah. Rangelands 20:17-25.

Bartos, D.L. and R.B. Campbell. 1998b. Water depletion and other ecosystem values forfeited when conifer forests displace aspen communities. In: D.F. Potts (Ed), 1998. proceedings of AWRA Specialty Conference, Rangeland Manage. and Water Resour., Amer. Water Resourc. Assoc., Herndon, Virg., TPS-98-1, 474pp.

Bartos, D.L. and N.V. DeByle. 1981. Quantity, decomposition, and nutrient dynamics of aspen litterfall in Utah. For. Sci. 27:381-390.

Bartos, D.L. and W.F. Mueggler. 1981. Early succession in aspen communities following fire in western Wyoming. J. Range Manage. 34:315-318.

Bartos, D.L., J.K. Brown, and G.D. Booth. 1994. Twelve years biomass response in aspen communities following fire. J. Range Manage. 47:79-83.

Bartos, D.L., W.F. Mueggler, and R.B. Campbell. 1991. Regeneration of aspen suckering on burned sites in Western 
Wyoming. USDA For. Ser. Gen. Tech. Rep. INT-448.

Bates, J.D., T.J. Svejcar, and R.F. Miller. 2002. Effects of juniper cutting on nitrogen mineralization. J. Arid. Environ. (in press).

Brown, J.K. and N.V. DeByle. 1987. Fire damage, mortality, and suckering in aspen. Can. J. For. Res. 17:1100-1109.

Cronquist, A., N.H. Holmgren, J.L. Reveal, and P.K. Holmgren. 1972. Intermountain flora. New York Bot. Garden, Bronx, N.Y.

DeByle, N.V. 1985. Animal impacts. p.115-123. In: N.V. Debyle and R.P. Winokur (eds.) Aspen: ecology and management in the Western United States. USDA For. Ser. Gen. Tech. Rep. RM-119.

DeByle, N.V., P.J. Urness, and D.L. Blank. 1989. Forage quality in burned and unburned aspen communities. USDA For. Ser. Gen Tech. Rep. INT-404.

Gifford, G.F., W. Humphries, and R.A. Jaynes. 1983. A preliminary quantification of the impacts of aspen to conifer succession on water yield within the Colorado River Basin (A process aggravating the salt pollution problem). Utah State Univ., Water Res. Lab., Hydralics. and Hydrol. Series UWL/II83/01, Logan, Utah.

Gifford, G.F., W. Humphries, and R.A. Jaynes. 1984. A preliminary quantification of the impacts of aspen to conifer succession on water yield. II. Modeling results. Water Res. Bull. 20:181-186.

Houston, W.R. 1954. A condition guide for aspen ranges of Utah, Nevada, southern Idaho, and western Wyoming. USDA For. Ser. Pap. INT-32.

Jaynes, R.A. 1978. A hydrologic model of aspen-conifer succession in the western United States. USDA For. Ser. Res. Pap. INT-213.
Johnston, R.S. 1971. Rainfall interception in a dense Utah aspen clone. USDA For. Ser. Res. Note INT-143.

Jones, J.R., and N.V. DeByle. 1985. Morphology. p. 11-18 In: Debyle, N.V. and R.P. Winokur (eds.) Aspen: ecology and management in the Western United States. USDA For. Ser. Gen. Tech. Rep. RM-119.

Kay, C.E. 1997. Is aspen doomed? J. For. 95: 4-11.

Kay, C.E. and D.L. Bartos. 2000. Ungulate herbivory on Utah aspen: assessment of longterm exclosures. J. Range Manage. 53:145-153.

Larsen, R.E. 1993. Interception and water holding capacity of western juniper. Ph.D Diss. Oregon State Univ. Corvallis, Ore.

Maser, C., J.W. Thomas, and R.G. Anderson. 1984. Wildlife habitats in managed rangelands - the Great Basin of southeastern Oregon - the relationship of terrestrial vertebrates to plant communities. Part 1, Text. USDA For. Ser. Gen. Tech. Rep. PNW-172.

McDonough, W.T. 1985. Sexual reproduction, seeds, and seedlings. p. 25-28 In: N.V. Debyle and R.P. Winokur (eds.) Aspen: ecology and management in the Western United States. USDA For. Ser. Gen. Tech. Rep. RM119.

Miller, R.F. and J. Rose. 1995. Historic expansion of Juniperus occidentalis (western juniper) in southeastern Oregon. Great Basin Natur. 55:37-45.

Miller, R.F. and J. Rose. 1999. Fire history and western juniper encroachment in sagebrush steppe. J. Range Manage. 52:550-559.

Miller, R.F. and P.E. Wigand. 1994. Holocene changes in semiarid pinyonjuniperwoodlands. BioSci. 44:465-474.
Miller, R.F., T.J. Svejcar, and J.F. Rose. 2000. Impacts of western juniper on plant community composition and structure. J. Range Manage. 53:574-585.

Miller, R.F., T.J. Svejcar, and N.E. West. 1994. Implications of livestock grazing in the Intermountain sagebrush region: plant composition. p. 101-146. In: M. Vavra, W.A. Laycock, and R.D. Pieper, (eds.), Ecological Implications of Livestock Herbivory in the West. Soc. Range Manage., Denver, Colo.

Mitton, J.B. and M.C. Grant. 1996. Genetic variation and the natural history of quaking aspen. BioSci. 46: 25-31.

Mueggler, W.F. 1985. Vegetation associations. p. 45-56 In: N.V. Debyle and R.P. Winokur (eds.) Aspen: ecology and management in the Western United States. USDA For. Ser. Gen. Tech. Rep. RM-119.

Mueggler, W.F. 1989. Age distribution and reproduction of Intermountain aspen stands. West. J. Appl. For. 4:41-45.

Romme, W.H., M.G. Turner, L.L. Wallace, and J.S. Walker. 1995. Aspen, elk, and fire in northern Yellowstone National Park. Ecol. 76:2097-2106.

SAS Institute. 1990. User's guide, version 6.03 edition. SAS Institute, Cary, N.C.

Tausch, R.J., N.E. West, and A.A. Nabi. 1981. Tree age and dominance patterns in Great Basin pinyon-juniper woodlands. J. Range Manage. 34:259-264.

Young, J.A., and R.A. Evans. 1984. Stem flow on western juniper (Juniperus occidentalis) trees. Weed Sci. 32:320-327. 